79.

\title{
診断用 X線防護服の新しい評価法の検討
}

\author{
石心会狭山挤院 \\ ○垭木 毅 \\ (Tuyoshi Sasaki) \\ 渡辺一典 \\ (Kazunor i Watanabe)
}

\author{
放身線空 \\ 松元 和繁 \\ (Kazutoshi Matumoto) \\ 柚木園 隆 \\ (Takashi Yukizono)
}

\author{
金茾竟弘 \\ (Yoshihiro Kanai) \\ 盛 伸二 \\ (Shinji Mori)
}

【目的】現在、防護服は各社多種多様のものが市販されているが、その性能は鉛当量で表示されてい る製品が大部分である。これはJIS規格 Z 4803-1980によるもので、0.25mmPb，0.35mmPb，0.50mmPb の3 種類の表示により、許容差を0〜+20\%と規定した表示法をそのまま使用しているにすぎない。例 えば、0.35 0.42 $\mathrm{mmPb}$ 性能を有する防護服は、総て $0.35 \mathrm{mmPb}$ 表示される。そのため同一表示の防 護服であっても、全く同じ性能を持つと言うわけではなく、防護服の違いにより術者の被曝には差が 現れる。このことは、医療従事者の長期にわたる防護という観点から考元れば、不十分な表示法であ り、防護服を製造又は、選定する際の大きな問題点であると考元られる。そこで今回我々は、実状に 合った方法で防護服の透過線量を測定し、その性能差を認識し、現行の評価法の問題点を述へ、、今後 の性能評価法の検討を行ったので報告する。

【方法】透視状態にてファントムより発生する散乱線を使用し、防護服の胸の部分からの透過線量を 電離箱により測定した。又、それを遮蔽率と透過率とで表した。測定した試料は、任意に集めた 0.35

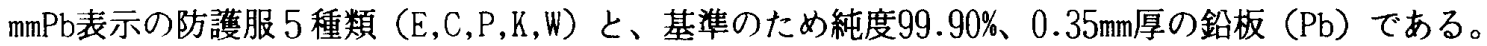
ファントムは $30 \mathrm{~cm} \times 30 \mathrm{~cm} \times 1 \mathrm{~cm}$ のアクル板20枚を使用した。X線管焦点からファントム底辺間距離は、

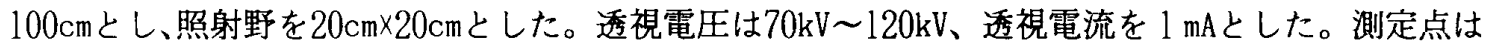

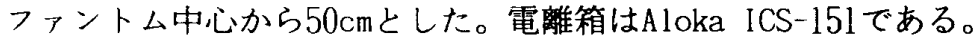

\section{【結果】}

○測定した試料はすべて鉛板Pbより も低い値を示し、0.35mmPb以上の製 品であることが分かる。又、それら はほぼ同形のラインを描いた。

(Fig. 1)

○同一表示の製品でありながら、そ

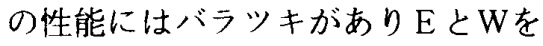
比較すると、散乱線透過率では 2 3 倍の差が現れ、100kVに於いて1時間 あたり、3.66 $\times 10^{-7} \mathrm{C} / \mathrm{kg}$ 差を示した。 (Fig. 2)

\section{【考察及び検討】}

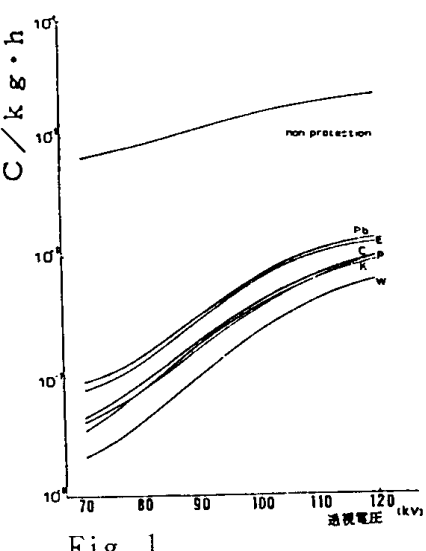

Fig. 1

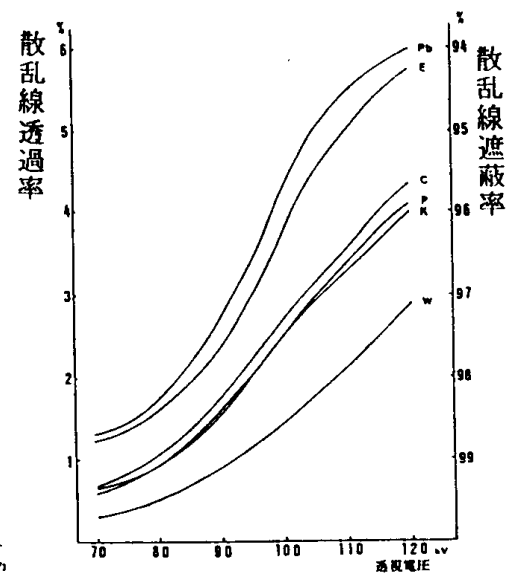

Fig. 2

I . 同一表示の防護服であっても、各社製造の違いによる透過線量数\%の差が、 $2 〜 3$ 倍の被曝線量 となることが我々の実験においても確認された。このことは、比較的被曝する機会の多い、循環器 或いは消化器系検査に従事する者に対しての、長期にわたる防護を考えた場合問題である。

II . 鉛当量による表示法は一見簡便であるが、防護服の正確な鉛当量とその時の精密な遮蔽曲線が必 要であり、どちらかが久ければ、単なる目安としかならず、その性能差を容認する結果となる。 III. 表示值は、 $100 \mathrm{kV} \quad 2.5 \mathrm{mmCu}$ 以上の線質のX線により試験される。それに対し、臨床場対象とな る散乱線の線質は、エネルギー成分の帯域が広く又、低くなる為、遮蔽曲線のグラフにより、鉛当 量に対する透過線量率の差は、試験時と比べて大きくなる傾向にある。

以上により、現行の鉛当量だけによる性能表示法は、許容差が大きすぎる為に不十分である。

そこで今回我っは、防護服の新しい評価法として次のことを提案する。

（1）ある決めら扎た実験下における散乱線透過率を、明確な約束をもって統一表示する。

(2)併せて、鉛当量も表示する。 